\author{
Olexander Bondarenko, Valerii Kapeliushnyi, Mykola Tupchiyenko, Dmytro Shvets \\ https://doi.org/10.26485/AAL/2021/67/4
}

\title{
A HOARD OF RUSSIAN COINS OF THE 18TH CENTURY FROM THE VILLAGE OF EMYLIVKA (HOLOVANIVSKY DISTRICT OF KIROVOHRAD REGION)
}

\begin{abstract}
In the spring of 2020 in the vicinity of the village Yemylivka (Golovanivskyi district, Kirovohrad region) local residents carrying out agricultural work accidentally discovered a hoard placed in a clay pot (Fig. 1). The deposit comprised coins which were in circulation in the Russian Empire during the XVIII century. The vast majority of the coins in the hoard are large-format copper 5 kopeck coins amounting to 40 pieces, as well as two silver rubles. Accordingly, the total value of the deposit is 4 rubles. The oldest coin of the complex is a ruble of 1731, and the youngest a 5 kopeck piece of 1786 . The presence in this coin deposit of the XVIII century of only 2 silver rubles, minted in the 1730s, indicates the insignificant presence of large denomination silver coins in the money market of southern Ukrainian lands on the border with the Polish-Lithuanian Commonwealth in the last quarter of the XVIII century. This is due to the monetary policy of the Russian authorities in Ukraine, relating to a ban on the export of silver coins outside the empire. This hoard of Russian coins of the XVIII century, which has already been the object of scientific attention, has several interesting features, in particular the presence in the hoard of two silver ruble coins, which furthermore are previously undescribed varieties. This hoard expands the our knowledge about the circulation of money in the Southern Ukraine in the XVIII century, especially in the lands bordering the Polish-Lithuanian Commonwealth.
\end{abstract}

Key words: Southern Ukraine, hoard of coins, ruble, copper coin

\author{
SKARB MONET ROSYJSKICH Z XVIII WIEKU \\ ZNALEZIONY WE WSI EMILEVKA, REGION KIROVOGRAD
}

\begin{abstract}
ABSTRAKT Wiosną 2020 r. w pobliżu wsi Jemulivka (region Kirovograd, Ukraina), podczas prac rolnych, natrafiono na gliniane naczynie wypełnione monetami - rosyjskimi monetami z XVIII stulecia. Dominują monety o nominale 5 kopiejek (40 sztuk). Obok nich były dwa srebrne ruble. Najstarszymi monetami są ruble z 1731 roku. Najmłodsza moneta to 5 kopiejek z 1786 roku. Publikowany skarb jest świadectwem obiegu monet na terenie Ukrainy, na granicy z Rzeczpospolitą. Odzwierciedla on obieg monetarny w ostatniej ćwierci XVIII wieku.
\end{abstract}

Słowa kluczowe: Ukraina, Rzeczpospolita, skarb monet

The hoard of coins, which were minted during the middle and second half of the 18th century, reflect the circulation of money in the Ukrainian territories controlled by the Russian Empire at that time. At the same time, hoards of coins found during this period can provide valuable information about aspects of the political history of the region. Thanks to them, one can trace the tendency to economic expansion and the increasing influence in the region of the Russian Empire. Instead of Polish and other European coins, more and more hoards have coins belonging to the internal monetary circulation within the Russian Empire. Coin hoards in general, and of this period in particular, were actively studied during the XIX century, and this was largely due to the fundamental accumulation of archaeological information during the Archaeological Congresses. The works of M. Beljashevskij, ${ }^{1}$ A. Danilevich, ${ }^{2}$ V. Shugaevskij ${ }^{3}$ were already published during the period of the Russian Empire.

The works of professors V. Orlyk, ${ }^{4}$ I. Spasskij, V. Uzdenikov, ${ }^{6}$ M. Kotliar, ${ }^{7}$ R. Shust, ${ }^{8}$ and

1 Beljashevskij 1899.

2 Danilevich 1905.

3 Shugaevskij 1911.

4 Orlyk 2008.

Spasskij 1970.

Uzdenikov 1986; Uzdenikov 1994.

Kotliar 1981.

Shust 2007. 
V. Nechytailo ${ }^{9}$ have been devoted to the question of the history of monetary circulation on the territory of the Russian Empire in the 18th century. The issue of money circulation in the Southern Ukraine, on the other hand, has been dealt with by the researches of V. Pivorovych, ${ }^{10} \mathrm{M}$. Orlyk ${ }^{11}$ and O. Skorokhod. ${ }^{12}$ A. Bojko-Gagarin covers the issue of counterfeit coins, including those found in hoards. ${ }^{13} \mathrm{M}$. Mielczarek, ${ }^{14} \mathrm{~K}$. Myzgin and V. Orlyk ${ }^{15}$ have also made significant contributions to Ukrainian numismatics, and coin hoards found on the territory of Ukraine.

The relevance and significant scientific importance of introducing new coin finds into scientific discourse was assessed by prof. V. Kotsur as one of the priority areas of numismatic research. ${ }^{16} \mathrm{He}$ thoroughly argued his thesis giving as examples the study of hoards, ${ }^{17}$ museum collections and archival sources. ${ }^{18}$

In the spring of 2020 local residents accidentally discovered a hoard placed in a clay pot during the course of agricultural work in the vicinity of the village Yemylivka (Golovanivskyi district of the Kirovohrad region) (Fig. 1). The deposit included coins circulating within the Russian Empire during the 18 th century. The vast majority of the coins in the hoard are large-format copper 5 kopeck coins, amounting to 40 examples, as well as two silver rubles. Accordingly, the total value of the deposit is 4 rubles. Data on coins are listed in Table 1.

The two silver rubles struck during the reign of Anna Ioanivna (1730-1740) immediately attract our attention. The ruble of 1731 (Fig. 2) has in the centre on the obverse an image of the portrait of the Empress, facing right. There are 5 "shoulder-flaps" with festoons and shamrocks under the ribbon of the Empress's dress and the edge of the corsage is parallel to the edge of the coin, which determines the type of obverse as being № 7 according to the catalogue of V. Bitkin. The reverse depicts the coat of arms of the Russian Empire in the form of a double-headed eagle with crowns on their heads, a double linear shield with the coat of

9 Nechytailo 2019.

10 Pivorovych 2009.

11 Orlyk 2012: 247-249.

12 Skorokhod 2015: 75-77.

13 Bojko-Gagarin 2015: 95-115

14 Mielczarek, Orlyk 2019: 33-39.

15 Orlyk 2016: 93-97; Orlyk 2017: 37.

16 Kotsur 2013: 3-8.

17 Kotsur 2017: 15-33; Orlyk, Kotsur, Tsyganenko 2019: 37-48.

18 Kotsur, Boiko-Gagarin 2019: 66-77. arms of Moscow (St. George the Victorious striking a snake to the right) on the chest and a cross with a chain of the Order of St. Andrew the FirstCalled. The presence of crosses in the crowns above the eagles' heads and the absence of dots as dividers of the legend determine the reverse to be of type № 2 or № $3^{19}$. The ruble is mainly interesting for the presence of a re-engraved date, being minted with the die stamp for a 1730 coin, with the last digit of the date corrected from " 0 " to "1". This indicates mainly that this kind of ruble of the Empress is the earliest issue of 1731, struck during the first months of activity of the mint. Re-engraving of dates is not uncommon for the Modern Period and the Middle Ages ${ }^{20}$ but with the improvement of machine minting technology, this phenomenon is virtually nullified. We also failed to detect this re-engraved example in the numismatic catalogues, which allowed us to introduce this ruble with its re-engraved date into scientific literature for the first time. The weight of the ruble is $25.88 \mathrm{~g}$, which does not exceed the norm. In the field there are marks of damage as well as abrasion of the parts of the image in higher relief incurred during circulation.

The high detail of portraits on Russian coins is becoming more and more diverse just on the silver rubles of Anna Ioanovna, starting from 1730. ${ }^{21}$

The second ruble was minted in 1736 (Fig. 3). On the obverse in the centre there is a portrait of the Empress with a distinctive feature - a pendant with 3 pearls on the chest, no ribbon on the left shoulder and 9 pearls in the hair, which defines the type of the coin as № 4.1 according to the catalogue of V. Bitkin. ${ }^{22}$ This ruble also has a distinctive feature - the presence of a dot between the first two digits of the date, and so " $1{ }^{\circ} 736$ ", which we also did not find in the numismatic catalogues. The weight of the ruble is $25.62 \mathrm{~g}$, which does not exceed the norm. These groups of rubles are decorated with floral ornaments as №10 according to the catalog of V. Bitkin.

The other part of the hoard consists of copper 5 kopeck coins of different dates, minted mainly at the Yekaterinburg Mint. ${ }^{23}$ The coins mostly have a green patina on their field. These copper coins have serious wear and tear, which indicates their previous use in the money supply. By the way,

19 Bitkin-a 2003: 476-477.

20 Bojko-Gagarin, Bagdonas, Denisenko 2016: 8-9.

21 Vall 2014: 114.

22 Bitkin-b 2003: 491.

23 Demmeni 1898: 76. 
A HOARD OF RUSSIAN COINS OF THE 18TH CENTURY...

Table 1. Catalogue of the coin hoard

\begin{tabular}{|c|c|c|c|}
\hline Denomination & Year of minting & Mint & Bibliography \\
\hline Ruble & 1731 & Kadashevskyi, Moscow & - \\
\hline Ruble & 1736 & Kadashevskyi, Moscow & $\begin{array}{c}\text { Bitkin № } 129 \\
\text { (undescribed variation) }\end{array}$ \\
\hline 5 kopecks & 1760 & Yekaterinburg & Bitkin № 440 \\
\hline 5 kopecks & 1760 & Yekaterinburg & Bitkin № 440 \\
\hline 5 kopecks & 1763 & Krasnyi, Moscow & Bitkin № 521 \\
\hline 5 kopecks & 1766 & Yekaterinburg & Bitkin № 524 \\
\hline 5 kopecks & 1766 & Krasnyi, Moscow & Bitkin № 524 \\
\hline 5 kopecks & 1766 & Yekaterinburg & Bitkin № 612 \\
\hline 5 kopecks & 1768 & Yekaterinburg & Bitkin № 614 \\
\hline 5 kopecks & 1768 & Yekaterinburg & Bitkin № 614 \\
\hline 5 kopecks & 1769 & Yekaterinburg & Bitkin № 616 \\
\hline 5 kopecks & 1771 & Yekaterinburg & Bitkin № 620 \\
\hline 5 kopecks & 1772 & Yekaterinburg & Bitkin № 621 \\
\hline 5 kopecks & 1773 & Yekaterinburg & Bitkin № 622 \\
\hline 5 kopecks & 1773 & Yekaterinburg & Bitkin № 622 \\
\hline 5 kopecks & 1775 & Yekaterinburg & Bitkin № 624 \\
\hline 5 kopecks & 1777 & Yekaterinburg & Bitkin № 626 \\
\hline 5 kopecks & 1777 & Yekaterinburg & Bitkin № 626 \\
\hline 5 kopecks & 1778 & Yekaterinburg & Bitkin № 627 \\
\hline 5 kopecks & 1781 & Yekaterinburg & Bitkin № 632 \\
\hline 5 kopecks & 1786 & Yekaterinburg & Bitkin № 637 \\
\hline 5 kopecks & $17(? ?)$ & Yekaterinburg & Unidentifiable \\
\hline 5 kopecks & $17(? ?)$ & Yekaterinburg & Unidentifiable \\
\hline 5 kopecks & $17(? ?)$ & Yekaterinburg & Unidentifiable \\
\hline 5 kopecks & $17(? ?)$ & Yekaterinburg & Unidentifiable \\
\hline 5 kopecks & $17(? ?)$ & Yekaterinburg & Unidentifiable \\
\hline 5 kopecks & $17(? ?)$ & Yekaterinburg & Unidentifiable \\
\hline 5 kopecks & $17(? ?)$ & Yekaterinburg & Unidentifiable \\
\hline 5 kopecks & $17(? ?)$ & Yekaterinburg & Unidentifiable \\
\hline 5 kopecks & $17(? ?)$ & Yekaterinburg & Unidentifiable \\
\hline 5 kopecks & $17(? ?)$ & Yekaterinburg & Unidentifiable \\
\hline 5 kopecks & $17(? ?)$ & Yekaterinburg & Unidentifiable \\
\hline 5 kopecks & $17(? ?)$ & Yekaterinburg & Unidentifiable \\
\hline 5 kopecks & $17(? ?)$ & Yekaterinburg & Unidentifiable \\
\hline 5 kopecks & $17(? ?)$ & Yekaterinburg & Unidentifiable \\
\hline 5 kopecks & $17(? ?)$ & Yekaterinburg & Unidentifiable \\
\hline 5 kopecks & $17(? ?)$ & Yekaterinburg & Unidentifiable \\
\hline 5 kopecks & $17(? ?)$ & Yekaterinburg & Unidentifiable \\
\hline 5 kopecks & $17(? ?)$ & Yekaterinburg & Unidentifiable \\
\hline 5 kopecks & $17(? ?)$ & Yekaterinburg & Unidentifiable \\
\hline 5 kopecks & $17(? ?)$ & Yekaterinburg & Unidentifiable \\
\hline 5 kopecks & 17(??) & Yekaterinburg & Unidentifiable \\
\hline
\end{tabular}



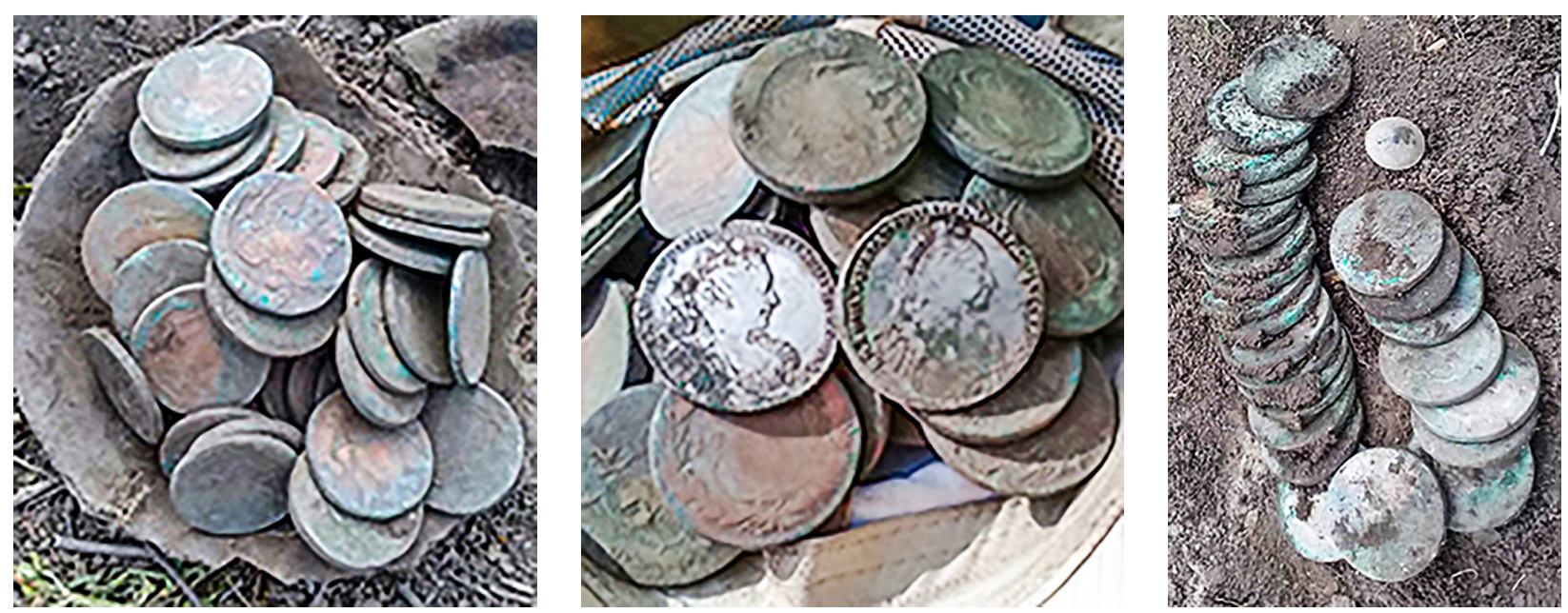

Fig. 1. Coin hoard of the Russian Empire from the village Yemylivka, Golovanivskyi district, Kirovohrad region (general view)

prof. O. Potylchak on the basis of regional research into the hoards found in the village Trushkiv in Bila Tserkva (Kyiv region) notes that Russian coins of the second half of 18 th century had serious wear and tear and concludes that they were intensively used in commercial exchanges. ${ }^{24}$

Five-copeck coins of this type first appeared in 1757. They were minted at the Yekaterinburg Mint. After 1758 their minting was also continued at the Red Mint in Moscow at the weight of 16 rubles per pood of copper, ie the weight of new coins reached at least 50 grams, replacing the previously common lighter "cross" pennies ${ }^{25}$ which were bought from the population for 2 kopecks in $1757 .{ }^{26}$

The wear or corrosion suffered by many of the coins does not allow us to determine the exact year of their minting. The issue of coins of this type continued in Yekaterinburg until 1796. ${ }^{27}$ Among the coins with a clearly defined year of minting, we found the majority to be 5 kopeck coins recently struck in 1786 . This makes it possible to date the deposit to the end of 1786 to the middle of 1787. Otherwise the deposit would contain coins minted in later years. Among the coins there are no samples of re-minted coins, neither the rare issues of the Sestroretsk and Suzun mints. The extreme upper date of 1786 excludes the presence in the hoard of coins struck in the Taurian Mint: the five-Kopeck coins struck in 1787 and 1788, as well as coins of the Annin Mint struck in 1789-1796.

\footnotetext{
24 Potylchak 2018: 119-131.

25 Bitkin-b 2003: 578-582

26 Uzdenikov 1994: 97.

27 Bitkin-b 2003: 661.
}

The Ukrainian scholar M. Kotlyar, based on his research conducted into archival documents, established the full use of the ruble as only becoming established after $1735 .{ }^{28}$ But the presence of two examples of ruble coins of the 1730s in the hoard, which can be dated to the end of the 18th century, casts some doubt on his conclusions.

The predominant number of five kopeck-coins indicates their high popularity among the population, although other coin finds also indicate a significant prevalence of coins of smaller denomination. ${ }^{29}$ Furthermore the presence in the hoard of only 2 silver rubles minted in the 1730s indicates the insignificant presence of large silver coins in the money market of the southern lands lying on the border of the Commonwealth in the last quarter of the 18th century. This is due to the monetary policy of the Russian authorities in Ukraine, who banned on the export of silver coins outside the empire.

From the second half of the 17th century, Muscovy used the lands of the Hetmanate to conduct unsuccessful financial experiments, which aimed at the complete absorption of Ukrainian monetary circulation by Russian coins. But despite all the efforts of the Imperial authorities, it actually happened only in the middle of the XVIII century. ${ }^{30}$

Thus, the publication of this hoard of Russian coins of the 18th century has enriched our scientific knowledge in several ways. It contains two silver ruble coins, of previously unidentified types, and which also refute the thesis of the full use of silver 
rubles after 1735. The contents of the hoard further confirm the full domination of Russian coins in the monetary market of the Hetmanate not earlier than the middle of the 18th century. This hoard also expands our understanding of monetary circulation in the Southern Ukraine in the 18th century.
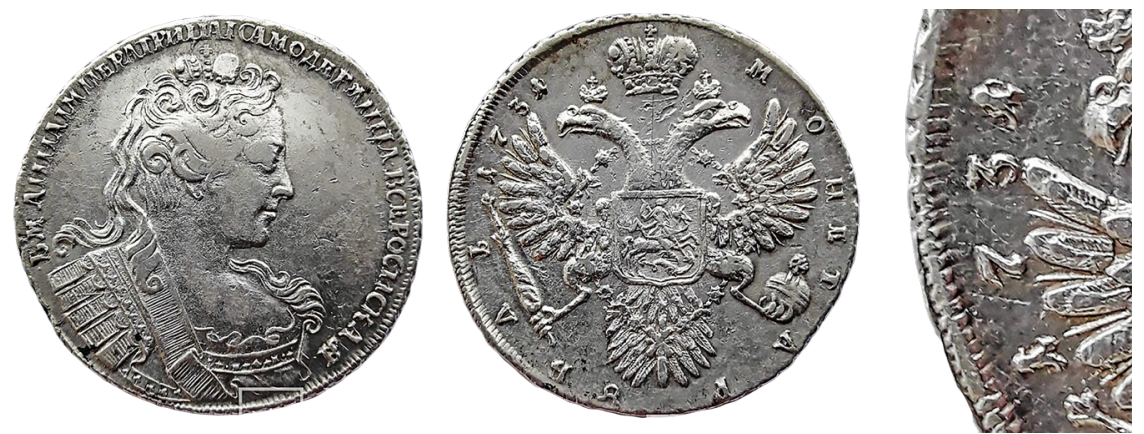

Fig. 2. Russian Empire, Anna Ioannovna, ruble in 1731
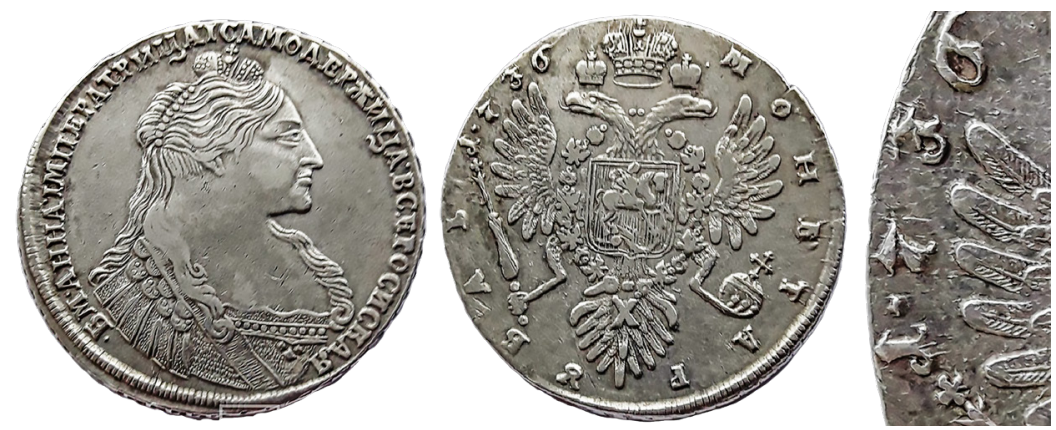

Fig. 3. Russian Empire, Anna Ioannovna, ruble in 1736
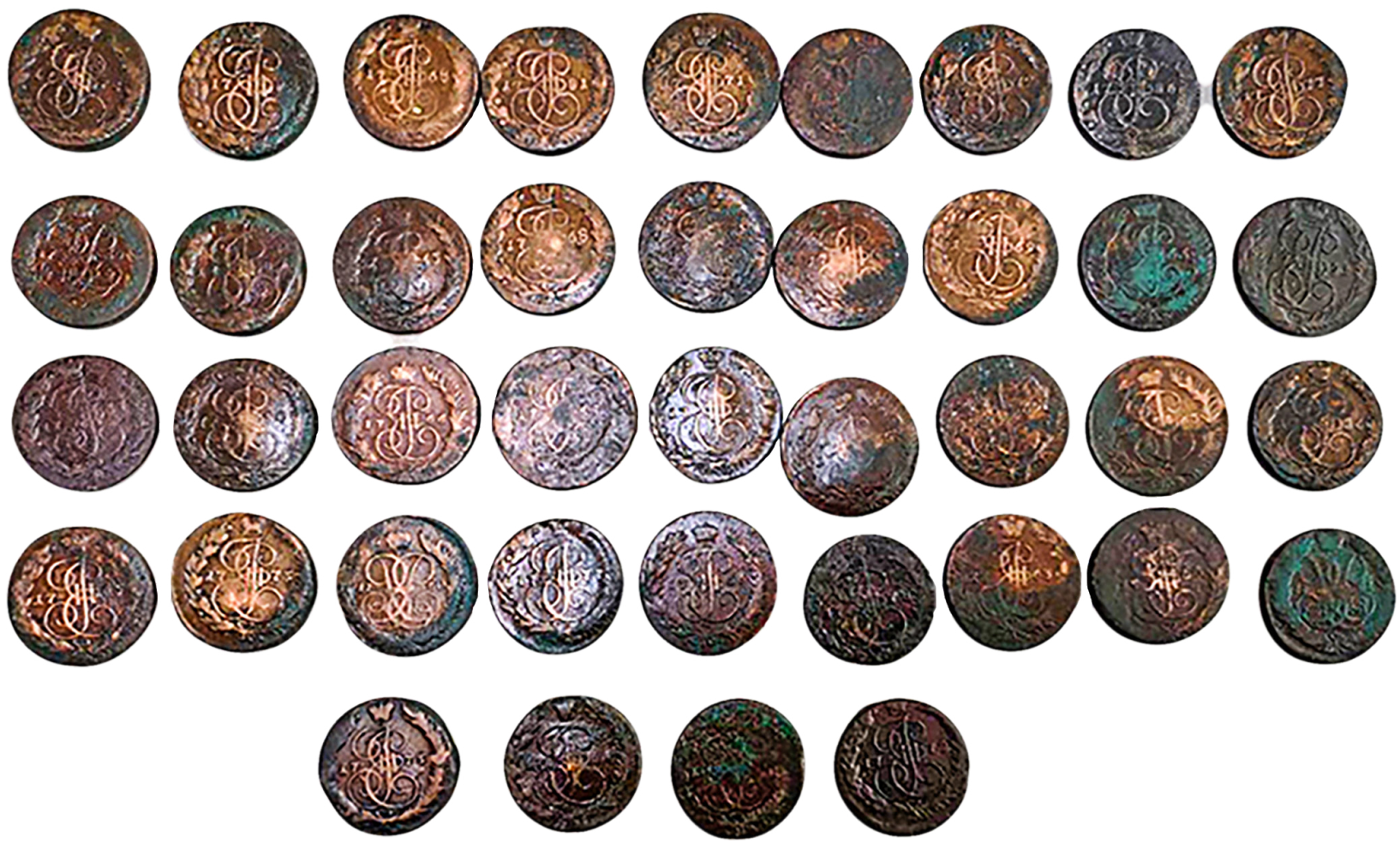


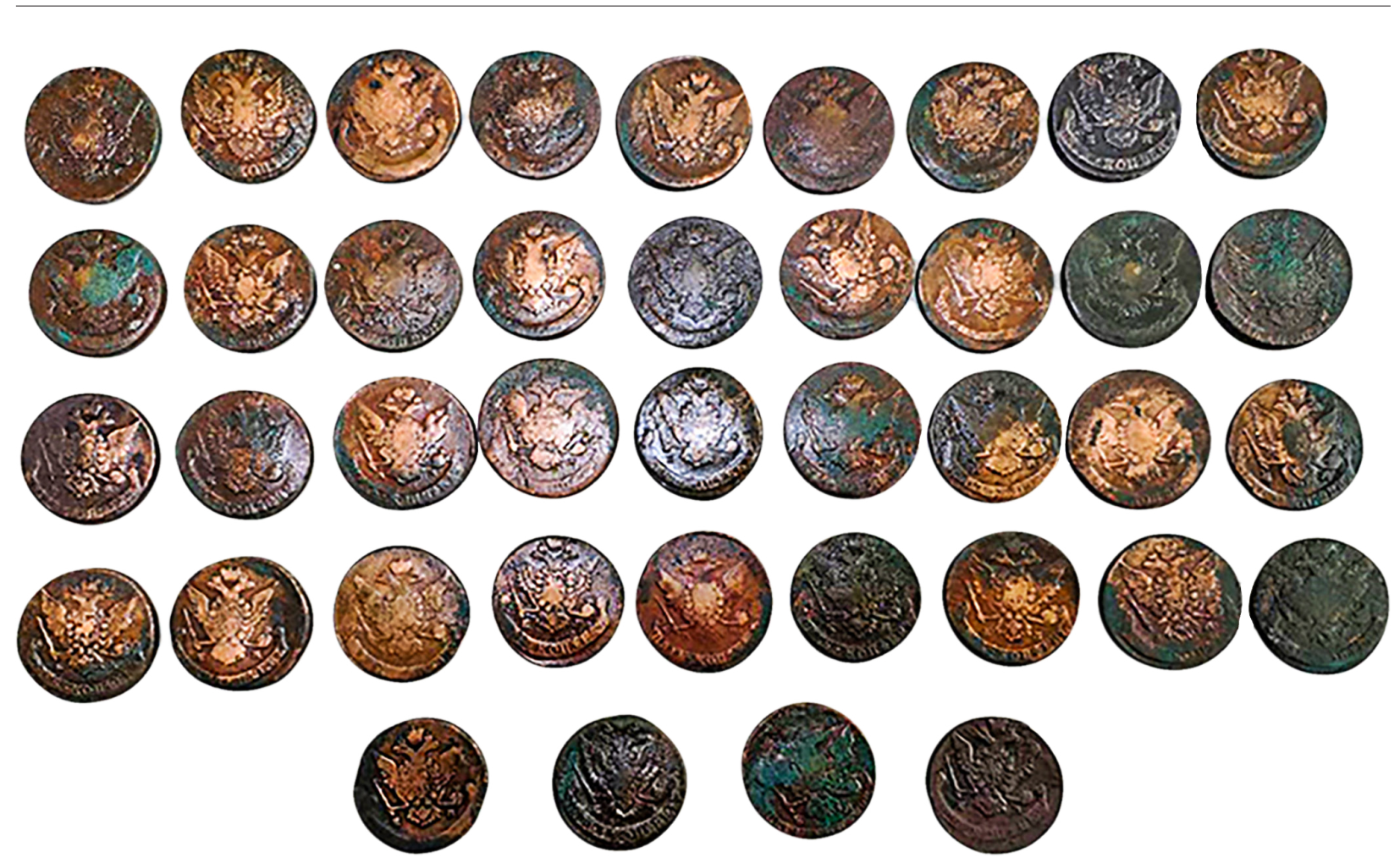

Fig. 4. Russian Empire, 5 kopecks 1760-1780’s

\section{References}

Arendar, H. P. \& Honcharenko, V. S. Holubytskyi skarb 2001 roku. [The Golubytsya treasure of 2001]. Skarbnytsia ukrainskoi kultury. [The treasury of the Ukrainian culture]. Ed. 4. Chernihiv, 2004. pp. 38-40. [in Ukrainian].

Beljashevskij, N. F. (1889) Monetnye klady Kievskoj gubernii. [The coin hoards of the Kyiv province]. Kiev. [in Russian].

Bitkin, V. V. (2003) Svodnyj katalog monet Rossii. Chast' I (1699-1740). [The consolidated catalog of Russian coins. Part I (1740-1917)]. Kiev: Junona-Moneta. [in Russian].

Bitkin, V. V. (2003) Svodnyj katalog monet Rossii. Chast' II (1740-1917). [The consolidated catalog of Russian coins. Part II (1740-1917)]. Kiev: Junona-Moneta. [in Russian].

Bojko-Gagarin, A. S. \& Bagdonas, G. \& Denisenko Ju. (2016) Novye neopisannye raznovidnosti monet Sigizmunda I Starogo (1506-1548) [The new unpublished varieties of the Sigismund I the Old (1506-1548) coins]. Numizmatika i faleristika. [Numismatics and faleristics]. (3). S. 8-9. [in Russian].

Bojko-Gagarin, A. S. (2017) Fal'shivomonetnichestvo v Central'noj i Vostochnoj Evrope v jepohu Srednevekov'ja i rannego Novogo vremeni [The coin counterfeiting in Central and Eastern Europe in the Middle age and early Modern time]. Kiev: Ukrainskaja konfederacija zhurnalistov. [in Russian].

Danilevich, V. E. (1905) Raskopki kurganov okolo s. Bud i h. Berjozovki Ahtyrskogo uezda Har'kovskoj gubernii. [The excavations of the mounds near Bud and Berezovka in Akhtyrsky district of Kharkov province]. Trudy XII arheologicheskogo sjezda v Har'kove. [Proceedings of the XII Archaeological Congress in Kharkov]. (1). [in Russian].

Demmeni, M. G. (1898) K istorii Ekaterinburgskogo monetnogo dvora. [To the history of the Yekaterinburg Mint]. Trudy Moskovskogo numizmaticheskogo obshhestva. Vol. 1. Moskva: Tipografija i Slovolitnja O.O. Gerbeka, Chernyshevskij per., 5. [in Russian].

Kotliar, M. F. (1981) Narysy istorii obihu y lichby monet na Ukraini XIV-XVIII st. [Essays on the history of circulation and counting of coins in Ukraine in the XIV-XVIII centuries.]. Kyiv: Naukova dumka. [in Ukrainian].

Kotsur, V. P. \& Boiko-Gagarin, A. S. (2019) Napoleon russian forged assignations in Naddniprianshchyna (over Dnipro land). East European historical bulletin. (11). 66-77. [in English].

Kotsur, V. P. (2013). Aktualni napriamy ta orhanizatsiini zasady suchasnykh doslidzhen serednovichnoi numizmatyky $v$ Ukraini. [Current trends and organizational principles of modern studies of medieval numismatics in Ukraine]. 
Naukovi zapysky z ukrainskoi istorii [The scientifical notes of the Ukrainian history]. (33), 3-8. [in Ukrainian].

Kotsur, V. P. (2017) Istoriohrafiia ukrainskoho skarboznavstva [The historiography of the Ukrainian treasurology]. Ukrainskyi Numizmatychnyi Shchorichnyk. 1. 15-33. [in Ukrainian].

Nechytailo, V. V. (2019). Hroshovyi obih na terytorii Hetmanshchyny (1648-1764 rr.). [Money circulation in the territory of the Hetman State (1648-1764)]. (Extended abstract of Candidate's thesis). 15 p. [in Ukrainian].

Orlyk, M. (2012) On the history of money Circulation in the territory of New Serbia and Elisavetgrad province (1750-1780S, XVIII century). Abstract of papers: Pieniadz i systemy monetarne wspolne dziedzictwo Europy. Studia I Materialy. Augustow - Warszawa, 2012. pp. 247-249. [in English].

Orlyk, V. M. (2008) Podatkova polityka uriadu Rosiiskoi imperii v kintsi XVIII - seredyni XIX st. [The Tax policy of the government of the Russian Empire in the late XVIII - mid XIX centuries].(Extended abstract of Doctor's thesis). 36 p. [in Ukrainian].

Orlyk, V., Kotsur, V. \& Tsyganenko, L. (2019). Klad ol'viyskikh monet «borisfenov», naydennyy v Gorodishchenskom rayone Cherkasskoy oblasti vesnoy 2018 goda. Acta Archaeologica Lodziensia, 65, 39-50. DOI: https://doi.org/10.26485/ AAL/2019/65/4 [in Russian].

Pivorovych, V. B. (2009) Monety i skarby pivdnia Ukrainy [The coins and hoards of the South Ukraine]. Kherson. [in Ukrainian].

Potylchak, O. (2018) Midna rosiiska moneta $v$ hroshovomu obihu Pravoberezhnoi Ukrainy u XVIII st. (na materialakh numizmatychnykh znakhidok 2017 roku z Trushkiv na Bilotserkivshchyni). [Copper Russian coin in circulation in the Right Bank of Ukraine in the XVIII century. (on the materials of numismatic finds of 2017 from Trushkiv in Bila Tserkva region)]. Ukrainskyi numizmatychnyi shchorichnyk [The Ukrainian numismatic annual]. 2. 119-131. [in Ukrainian].

Shugaevskij, V. A. (1911) O nauchnom znachenii monetnyh nahodok. [About the scientific significance of coin finds]. S.-Peterburg [in Russian].

Shust, R. M. (2009) Numizmatyka. Istoriia hroshovoho obihu ta monetnoi spravy v Ukraini. [Numismatics. History of monetary circulation and monetary affairs in Ukraine]. 2nd Ed. Kyiv: Znannia. [in Ukrainian].
Skorokhod, O. (2015) Do istoriohrafii hroshovoho obihu na Pivdni Ukrainy u doreformennyi period. [To the historiography of money circulation in the South of Ukraine in the pre-reform period]. Abstract of papers: III Mizhnarodna naukovo-praktychna konferentsiia «Aktualni problemy numizmatyky u systemi spetsialnykh haluzei istorychnoi nauky» [Actual problems of numismatics in the system of special branches of historical science]. 5-6 lystopada $2015 \mathrm{r}$. Kirovohrad-Kyiv-Pereiaslav-Khmelnytskyi. pp. 75-77. [in Ukrainian].

Spasskij, I. G. (1970) Russkaja monetnaja sistema. Istoriko-numizmaticheskij ocherk. [Russian monetary system. Historical-numismatic essay]. Ed. 4. Leningrad: Avrora. [in Russian].

Uzdenikov V. V. (1986) Monety Rossii 1700-1917. [The Russian coins 1700-1917]. Moskva: Finansy i statistika, 1986. $504 \mathrm{~s}$. [in Russian].

Uzdenikov, V. V. (1994). Monety Rossii XVIII nach. XX vv. Ocherki po numizmatike. [Coins of Russia XVIII - the beg. XX centuries Essays on Numismatics]. Moskva. 207 p. [in Russian]. Vall, A. (2014). Ispravlenie monetnogo dela pri Anne Ioannovne [The change of the coin affairsduring the Anna Ioanovna rule]. Zolotoj chervonec [The golden chervonets]. № 3 (28). Moskva, 2014. pp. 112-117. [in Russian].

Olexander Bondarenko, ORCID 0000-0001-8582-513X Central Ukrainian National Technical University (Kropyvnytskyi, Ukraine) o.v.bondarenko@ukr.net

Valerii Kapeliushnyi ORCID 0000-0002-3552-3675

Taras Shevchenko National University of Kyiv (Kyiv, Ukraine) v.kapelyushniy@meta.ua

Mykola Tupchiyenko ORCID 0000-0002-7076-4861

Central Ukrainian National Technical University (Kropyvnytskyi, Ukraine) tupchy_mp@ukr.net

Dmytro Shvets ORCID 0000-0002-2787-2672 Independent scientist (Kropyvnytskyi, Ukraine) shwez@gmail.com 